towards treating end stage renal failure in more elderly people and those with underlying diseases such as diabetes, and the less skilled they will be in diagnosing chronic renal failure. These findings suggest that intraregional variation should be examined more closely, as the findings may have implications for the organisation of treatment for end stage renal failure in the National Health Service.

We thank the strategic planning group, renal interest group, and clinical and scientific services directorate of North West Thames Regional Health Authority. We are also particularly grateful to Julie Kelly for her excellent secretarial help.

1 Wing AJ, Broyer M, Brunner FP, et al. Treatment of end stage renal failure in the United Kingdom: EDTA registry analysis. In: Bradley B, Moras D, eds. UK transplant service review 1982. Bristol: UK Transplant Service, 1983:33-64.

1982. Bristol: UK Transplant Service, 1983:33-64.
2 Dowie $R$. Deployment of resources in treatment of end stage renal failure in England and Wales. BrMed f 1984;288:988-91.

3 Weyman C. An analysis of factors affecting utilisation pattems of radiotherapy services. Warwick: University of Warwick, 1982. MSc dissertation.

4 Rostand SG, Kirk KA, Rutsky ER, Pate BA. Racial differences in the incidence of treatment for end stage renal disease. $N$ Engl f Med 1982;306:1276-9.

5 Challah S, Wing AJ, Bauer R, Morris RW, Schroeder SA. Negative selection of patients for dialysis and transplantation in the United Kingdom. Br Med f 1984;288:1119-22.

(Accepted 23 February 1987)

North West Thames Regional Health Authority, London W2 3QR

MAUREEN DALZIEL, MB, MFCM, specialist in community medicine

CHRIS GARRETT, BSC, deputy regional statistician

Correspondence to: Dr Dalziel.

\section{Loperamide toxicity in a child after a single dose}

Loperamide has been used in Britain for diarrhoea since 1975. Respiratory depression and coma may occur after overdosage ${ }^{1}$ and long term therapeutic use $^{2}$ and have been shown to be reversible by injection of naloxone. ${ }^{1}$ So far as we know the following is the first report of opioid toxicity after a single therapeutic dose.

\section{Case report}

A 15 month old girl weighing $8 \mathrm{~kg}$ was admitted to hospital after accidental scalding, superficial burns covering $35 \%$ of the body area. She was rehydrated with intravenous fluids, treated with flucloxacillin and penicillin, and on day 5 transferred to a plastic surgery unit for assessment. At the time she was taking fluids and had copious green watery diarrhoea. Clinical examination showed no other abnormality and she was well hydrated. Results of investigations were: haemoglobin concentration $94 \mathrm{~g} / \mathrm{l}$, urea and electrolyte values normal, stools negative for reducing sugars and culture, urine culture negative. The diagnosis was diarrhoea as a stress response to burns.

On day 9 she was still having the diarrhoea, and at 1330 she was prescribed an initial $1 \mathrm{mg}$ oral dose of loperamide. Fifty minutes later she was collapsed, pale, and unresponsive to pain; pulse was $120 / \mathrm{min}$ and respiratory rate $14 / \mathrm{min}$. She had not vomited or convulsed. She was resuscitated with oxygen by Ambu bag and given $0.3 \mathrm{mg}$ naloxone intravenously. By two minutes conscious level was improved and respiratory rate $30 / \mathrm{min}$. Next day she was still drowsy. Blood values were: haemoglobin $87 \mathrm{~g} / \mathrm{l}$, urea and electrolytes normal, alanine aminotransferase activity $327 \mathrm{U} / \mathrm{l}$, total protein $36 \mathrm{~g} / \mathrm{l}$, albumin $11 \mathrm{~g} / 1$. She was transfused $200 \mathrm{ml}$ whole blood and $100 \mathrm{ml}$ plasma protein fraction. Conscious level was normal on day 11 . Serum alanine aminotransferase activity was $76 \mathrm{U} / 1$, total protein concentration $48 \mathrm{~g} / \mathrm{l}$, and albumin concentration $18 \mathrm{~g} / \mathrm{l}$. The diagnosis was changed to cows' milk protein intolerance, as the diarrhoea resolved on withdrawal of milk.

Apart from antibiotics she received papaveretum $1.5 \mathrm{mg}$ intravenously on eight occasions on days $1-3$ and five doses of morphine elixir $2.5 \mathrm{mg}$ on days $3-5$ without ill effects. No opioids had been given within four days of the reaction to loperamide. At that time she was receiving up to $360 \mathrm{mg}$ paracetamol syrup daily and had had a single dose of $200 \mathrm{mg}$ chloral hydrate the previous evening.

\section{Comment}

The $1 \mathrm{mg}$ dose used for this child $(0 \cdot 125 \mathrm{mg} / \mathrm{kg})$ may have been greater than necessary, as the manufacturer's data sheet recommends the dose for children aged 4-8 as $1 \mathrm{mg}$ every six hours until diarrhoea settles, and Martindale states that loperamide should not be used in the very young. ${ }^{3}$ Doses in clinical trials have ranged from 0.045 to $4.0 \mathrm{mg} / \mathrm{kg} / \mathrm{day}$ with few side effects, though convulsions occurred in a 4 month old infant treated for 11 weeks, the dose being $4 \mathrm{mg} / \mathrm{kg} /$ day over the previous week, ${ }^{4}$ and possible ileus after a single dose of $0.045 \mathrm{mg} / \mathrm{kg}$ in a 1 year old. ${ }^{5}$

The reason for toxicity in this case is unclear. The low serum protein concentration may have been contributory (loperamide is $\mathbf{9 7 \%}$ protein bound) and absorption may have been increased by damage to the gut wall. The raised serum alanine aminotransferase activity suggests that a temporary hepatic disturbance might have impaired handling of the drug.

As loperamide is available over the counter, doctors should be alert to the possible hazards of accidental ingestion of this drug by small children and the specific treatment that may be required. Naloxone appears to be an effective antidote. Reports to the National Poisons Unit suggest that though this drug causes symptoms in most cases of accidental overdosage, serious toxicity is rare.

We thank Dr N R C Roberton and Mr R C Campbell, of Addenbrooke's Hospital, Cambridge, for permission to report this case.

1 Friedli G, Haenggeli C-A. Loperamide overdose managed by naloxone. Lancet 1980;i:1413.

2 Marcovitch H. Loperamide in "toddler diarrhoea." Lancet 1980;i:1413.

3 Reynolds JEF, ed. Martindale; the extra pharmacopoeia. 28th ed. London: Pharmaceutical Press, 1982: 1060-1.

4 Weaver LT, Richmond SWJ, Nelson R. Loperamide toxicity in severe protracted diarrhoea. Arch Dis Child 1983;58:568.

5 Von Muhlendahl KE, Bunjes R, Krienke EG. Loperamide induced ileus. Lancet 1980;i:209.

(Accepted 23 February 1987)

National Poisons Unit, Guy's Hospital, London SE1 9RT

N A MINTON, BSC, MRCP, medical registrar

Department of Paediatrics, Addenbrooke's Hospital, Cambridge CB2 2 QQ PG D SMITH, MA, MB, senior house officer

Correspondence to: Dr Minton.

\section{Insulinoma unmasked by the Cambridge diet}

Hypoglycaemia is not usually a feature of adherence to very low energy diets. We describe a patient who, for the first time, developed symptoms attributable to hypoglycaemia within three days of starting the Cambridge diet and was subsequently found to have an insulinoma.

\section{Case report}

A previously fit 46 year old man (height $179 \mathrm{~cm}$, weight $82 \mathrm{~kg}$, body mass index 25.6 ) was referred to the neurology department by his general practitioner because of a history of intermittent unsteady gait, slurred speech, and intellectual impairment which began three days after he started a self prescribed very low energy diet (the Cambridge diet; $1.38 \mathrm{MJ} /$ day. His wife described how, while out walking, he began to stagger and his speech became slurred. The patient described feelings of unsteadiness, weakness, and intoxication. The symptom completely resolved within 30 minutes of eating a light meal. Symptoms recurred two days later while he was still taking the Cambridge diet and again resolved after a light meal. Two days later he awoke confused and disorientated, wide eyed, and smiling inanely. On attempting to rise he staggered about the room. His symptoms resolved on eating breakfast. Physical examination showed no abnormality and investigations for spontaneous hypoglycaemia were initiated.

A random plasma glucose estimation while the patient was symptom free was $7 \cdot 1 \mathrm{mmol} / \mathrm{l}$. Next morning, after a 15 hour fast, the plasma glucose concentration was $2.6 \mathrm{mmol} / \mathrm{l}$ but unaccompanied by symptoms. The fast was continued with exercise. After 22 hours without food his responses to intellectual testing were slow and an electroencephalogram showed slight slowing of the $\alpha$ rhythm to $9 \mathrm{~Hz}$ during overbreathing. Intravenous injection of saline given as a control produced no change but $25 \mathrm{~g}$ glucose given similarly restored his mental state and returned the $\alpha$ rhythm to $10 \mathrm{~Hz}$. The preinjection plasma glucose concentration was $1 \cdot 6$ $\mathrm{mmol} / \mathrm{l}, \beta$-hydroxybutyrate concentration less than $0.02 \mathrm{mmol} / \mathrm{l}$, immunoreactive insulin concentration $55 \mathrm{mU} / 1$, and C peptide concentration $3.6 \mu \mathrm{g} / \mathrm{l}$. The finding of inappropriately high plasma insulin and $\mathrm{C}$ peptide values and suppressed $\beta$-hydroxybutyrate concentration in the presence of hypoglycaemia was highly suggestive of insulinoma. Computed tomography showed nothing abnormal.

At laparotomy a well encapsulated tumour $1 \mathrm{~cm}$ in diameter was removed from the posterior aspect of the head of the pancreas. Immunohistologically the tumour contained many insulin and a few somatostatin containing cells. Recovery was uneventful. Five days postoperatively the overnight fasting plasma glucose value was $7 \cdot 1 \mathrm{mmol} / \mathrm{l}$. Immunoreactive insulin $(6.7 \mathrm{mU} / \mathrm{l})$, C peptide $(3.3 \mu \mathrm{g} / \mathrm{l})$, and $\beta$-hydroxybutyrate $(0.12 \mathrm{mmol} / \mathrm{l})$ concentrations were all appropriate for the 
plasma glucose value. By using an antiserum which does not cross react with insulin (Guildhay Antisera, Guildford), much of the circulating immunoreactive insulin was subsequently shown to be proinsulin.

\section{Comment}

Very low energy diets have been used clinically as an aid to weight loss in gross obesity. ${ }^{1}$ The recent more general availability of such diets has enabled them to be used without medical supervision by people with moderate to minimal obesity. The present case illustrates an interesting though rare manifestation of very low energy intake; indeed, low energy, low carbohydrate diets were advocated as a provocative test for insulinoma in lieu of total fasting. ${ }^{2}$ Signs and symptoms of hypoglycaemia are not a feature of low energy diets in the absence of organic disease and their occurrence, as in this case, should lead to further investigation.

1 Vertes V. Very low calorie diets-history, safety and recent developments. Postgrad Med $\mathcal{J}$ 1984;60:56-8.

2 Conn JW, Seltzer HS. Spontaneous hypoglycemia. Am f Med 1955;19:460-78.

(Accepted 23 February 1987)

St Luke's Hospital and Royal Surrey County Hospital, Guildford, Surrey

M LABIB, MB, MRCPATH, senior registrar in clinical biochemistry

V MARKS, FRCP, FRCPATH, consultant in clinical biochemistry

J PATTEN, BSC, FRCP, consultant neurologist

P BARKER, MB, MRCP, senior house officer in neurology

S LAURENT, MB, BS, senior house officer in neurology

P BOULTER, FRCS, consultant surgeon

Correspondence to: Dr M Labib, Department of Clinical Biochemistry, St Luke's Hospital, Guildford, Surrey GU1 3NT.

\section{Verapamil in atrial fibrillation in hyperthyroidism}

Hyperthyroidism is a well known cause of atrial fibrillation, and until hyperthyroidism is properly controlled atrial fibrillation is often difficult to treat.' Verapamil is effective in the treatment of atrial fibrillation in euthyroid patients, ${ }^{2}$ and we therefore tried it in the treatment of hyperthyroid patients with atrial fibrillation.

\section{Patients, methods, and results}

Nine patients were included in the study, seven women and two men, aged 52 87. On admission hyperthyroidism was confirmed in all patients by finding raised hormone concentrations, and subsequently by the absence of any thyrotrophin response to thyrotrophin releasing hormone. At the time of verapamil treatmen one patient had received antithyroid treatment for one week: none of the remaining patients had received such treatment.

On admission all patients had atrial fibrillation with a heart rate of 120 beats min or more. Six patients had cardiac failure. Details of antiarrhythmic treatment and its effects are shown in the table. Seven patients received digoxin withou adequate control of heart rate, but after the addition of verapamil this was achieved in all patients. In case 4 , a patient who was unresponsive to a combination of digoxin and a $\beta$ blocker, the heart rhythm was immediately converted to sinus rhythm after intravenous verapamil. Two patients were treated with verapamil only, and both converted to sinus rhythm. One of these patients had an overt thyrotoxic crisis. In spite of this sinus rhythm was maintained with oral verapamil.

Verapamil caused no further deterioration of left ventricular function in any of the patients; advanced atrioventricular block was not observed.

\section{Comment}

Electrophysiological investigations of the heart in hyperthyroidism have shown a shortening of the action potential owing to an increased rate of diastolic depolarisation in atrial cells. ${ }^{3}$ This shortening predisposes to atrial fibrillation, ${ }^{2}$ which occurs in $15-30 \%$ of patients with hyperthyroidism and is often the presenting feature. Digoxin is usually the first drug of choice, but altered pharmacodynamics and decreased sensitivity to digoxin may make treatment difficult. Supplementary treatment with a $\beta$ blocker without an intrinsic sympathomimetic effect is often tried. Nevertheless, on admission a substantial number of patients with hyperthyroidism and atrial fibrillation have cardiac failure and $\beta$ blockers may further decrease the left ventricular function. ${ }^{45}$ Hence $\beta$ blockers are relatively contraindicated in these patients, and verapamil may be an alternative. Neither verapamil nor $\beta$ blockers affect the duration of the action potential of atrial muscle cells, but both have a pronounced effect on the conduction time of the atrioventricular node. ${ }^{23}$

Our results indicate that verapamil is effective in controlling the heart rate in hyperthyroid patients, even when digoxin or $\beta$ blockers, or both, have proved ineffective. Hence it is probably a suitable alternative to these, but randomised studies comparing all three agents in treating hyperthyroid patients with atrial fibrillation are needed.

1 Bristow MR, ed. Drug induced hearn disease. Amsterdam: Elsevier North Holland Biomedical Press, 1980:421-31.

2 Singh BN, Collett JT, Chew CYC. New perspectives in the pharmacological treatment of cardiac arrhythmias. Prog Vasc Dis 1980;4:243-301.

3 Johnson PN, Freedberg AS, Marshall JM. Action of thyroid hormone on the transmembrane potentials from sinoatrial node cells and atrial muscle cells in isolated atria of rabbits. Cardiology 1973;58:273-89.

$4 \mathrm{Ikram} \mathrm{H}$. Haemodynamic effects of beta-adrenergic blockade in hyperthyroid patients with and without heart failure. BrMed I 1977; i: 1505-7.

5 Pietras RJ, Real MA, Poticha GS, Bronsky D, Waldstein SS. Cardiovascular response in hyperthyroidism, the influence of adrenergic receptor blockade. Arch Intern Med 1972;129: 426-9.

(Accepted 23 February 1987)

Department of Cardiology, Hvidovre Hospital, Copenhagen, Denmark

C G DAHLSTRØM, MD, senior registrar

$S$ D LADEFOGED, MD, senior registrar

Correspondence to: Dr Dahlstrøm, 20B Middelvej, DK-2820 Gentofte, Denmark.

\section{Persistent mesenteric ischaemia in a young woman}

Mesenteric ischaemia is an uncommon cause of abdominal pain, usually being considered only in older patients with vascular or haematological disease. We describe a young woman with typical symptoms in whom the condition remained undiagnosed until emergency laparotomy despite investigation by five consultants in four hospitals over 18 months. Surprisingly, she later developed recurrent pain from ischaemia despite almost total resection of the small bowel.

Effects of antiarrhythmic treatment on nine patients with hyperthyroidism with atrial fibrillation on admission

\begin{tabular}{|c|c|c|c|c|c|c|}
\hline Case No & $\begin{array}{c}\text { Treatment on admission } \\
\text { (daily dose) }\end{array}$ & $\begin{array}{l}\text { Heart rate on admission } \\
\text { (beats } / \mathrm{min} \text { ) }\end{array}$ & Initial treatment & $\begin{array}{l}\text { Effect of initial treatment } \\
\text { (rhythm (beats/min)) }\end{array}$ & Verapamil dosage & $\begin{array}{l}\text { Effect of verapamil } \\
\text { treatment } \\
\text { (rhythm (beats/min)) }\end{array}$ \\
\hline $\begin{array}{l}1 \\
2\end{array}$ & Digoxin $125 \mu \mathrm{g} \times 2$ & $\begin{array}{l}120 \\
160\end{array}$ & $\begin{array}{l}\text { Verapamil } 80 \mathrm{mg} \times 3 \\
\text { Digoxin } 1000 \mu \mathrm{g}\end{array}$ & $\begin{array}{l}\text { Atrial fibrillation (70) } \\
\text { Atrial fibrillation (160) }\end{array}$ & $\begin{array}{l}80 \mathrm{mg} \times 3 \\
5 \mathrm{mg} \text { intravenously and } \\
80 \mathrm{mg} \times 4\end{array}$ & $\begin{array}{l}\text { Atrial fibrillation }(70) \\
\text { Intermittent sinus rhythm }\end{array}$ \\
\hline $\begin{array}{l}3 \\
4\end{array}$ & $\begin{array}{l}\text { Digoxin } 65.5 \mu \mathrm{g} \times 2 \\
\text { Digoxin } 125 \mu \mathrm{g} \times 2 \\
\text { propranolol } 40 \mathrm{mg} \times 4\end{array}$ & $\begin{array}{l}160 \\
160-180\end{array}$ & $\begin{array}{l}\text { Verapamil intravenously } \\
\text { Practolol (drip) }\end{array}$ & \multicolumn{2}{|c|}{$\begin{array}{l}\text { Intermittent sinus rhythm } 80 \mathrm{mg} \times 3 \\
\text { Atrial fibrillation (160-180) } 5 \mathrm{mg} \text { intravenously and by } \\
\text { drip and } 120 \mathrm{mg} \times 4\end{array}$} & $\begin{array}{l}\text { Intermittent sinus rhythm } \\
\text { Sinus rhythm }\end{array}$ \\
\hline $\begin{array}{l}5 \\
6\end{array}$ & & 160 & $\begin{array}{l}\text { Verapamil } 5 \mathrm{mg} \text { intravenously } \\
\text { Digoxin } 1000 \mu \mathrm{g}\end{array}$ & $\begin{array}{l}\text { Sinus rhythm } \\
\text { Atrial fibrillation (170) }\end{array}$ & $\begin{array}{l}80 \mathrm{mg} \times 3 \\
10 \mathrm{mg} \text { intravenously and by }\end{array}$ & $\begin{array}{l}\text { Sinus rhythm } \\
\text { Atrial fibrillation (100) }\end{array}$ \\
\hline 7 & & 160 & $\begin{array}{l}\text { Verapamil } 10 \mathrm{mg} \\
\text { intravenously and by drip }\end{array}$ & Sinus rhythm & $80 \mathrm{mg} \times 4$ & Sinus rhythm \\
\hline $\begin{array}{l}8 \\
9\end{array}$ & Digoxin $62.5 \mu \mathrm{g} \times 3$ & $\begin{array}{l}120 \\
150-160\end{array}$ & $\begin{array}{l}\text { Verapamil } 80 \mathrm{mg} \times 4 \\
\text { Digoxin } 1000 \mu \mathrm{g}\end{array}$ & $\begin{array}{l}\text { Atrial fibrillation (100) } \\
\text { Atrial fibrillation (140) }\end{array}$ & $\begin{array}{l}80 \mathrm{mg} \times 4 \\
5 \mathrm{mg} \text { intravenously and } \\
80 \mathrm{mg} \times 3\end{array}$ & $\begin{array}{l}\text { Atrial fibrillation (90) } \\
\text { Intermittent atrial } \\
\text { fibrillation (70) }\end{array}$ \\
\hline
\end{tabular}

